Л.В. ФАДЕЕВ, канд. техн. наук., доцент, директор ООО "Спецэлеватормельмаш"

\title{
ТОЧНАЯ АГРОТЕХНОЛОГИЯ БУДУЩЕГО НАЧИНАЕТСЯ СЕГОДНЯ. ПОДСОЛНЕЧНИК
}

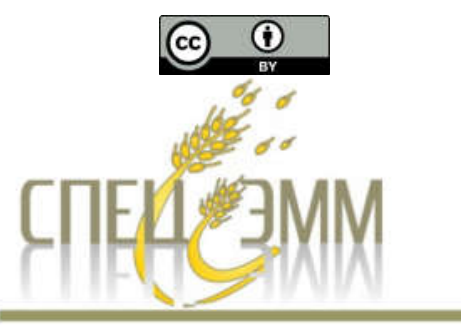

Не смотря на то, что принцип равнораспределения растений на поле универсален, имеются некоторые особенности для каждой культуры.

В то же время, я вполне допускаю, что жестокая засуха во второй половине сезона 2015 года оставляет возможность думать об оптимизации нормы высева и густоты стояния подсолнечника только отъявленному оптимисту. Но может быть, как раз этот материал и отвлечет от горьких мыслей и напомнит о том, что за неурожайным годом обязательно придет урожайный. И если встретить его во всеоружии знаний и возможностей, и в следующем сезоне сделать шаг к оптимизации сева, то в случае подтверждения эффективности рекомендаций, возможно, и в последующие, не лучшие по погоде года, не произойдет фатальной неурожайности. Тогда материал этот, по крайней мере, будет оправдан, ибо в нем содержится рекомендация, как помочь растению в борьбе с засухой.

Чуть отвлечемся от темы, вернее приподнимемся над ней.

Чем глубже анализируешь динамику изменения численности населения Земли и снижающийся потенциал производства продовольствия, тем прогнозы о мировом продовольственном кризисе представляются все более и более вероятными. Достаточно сказать, что за время жсизи одного челове
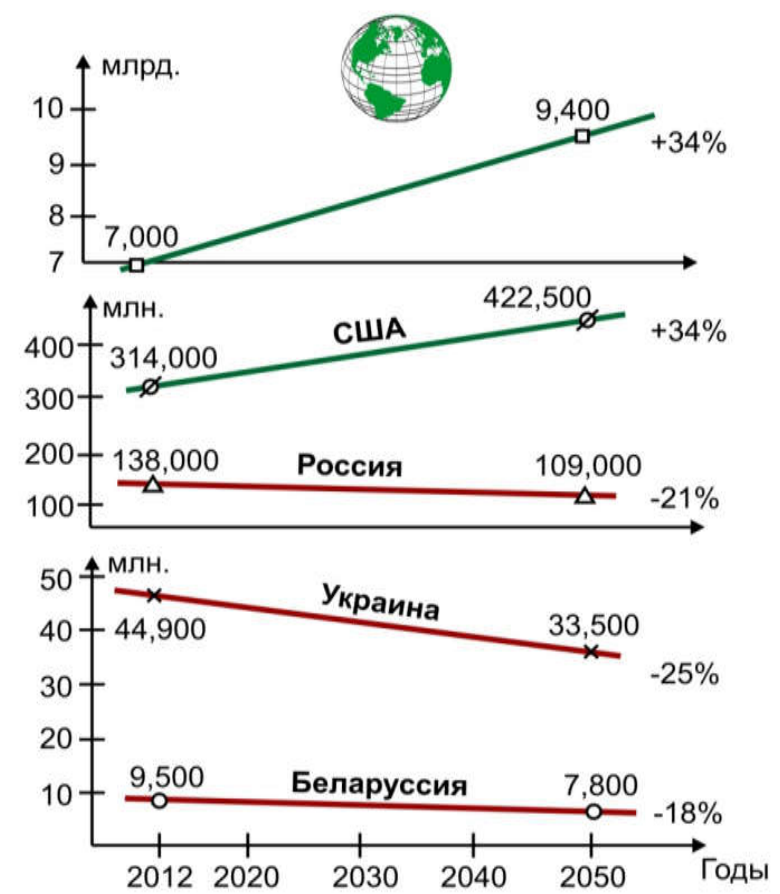

Рис. 1. Демографический прогноз до 2050 года* *no данным US Census Bureau, www.census.gov

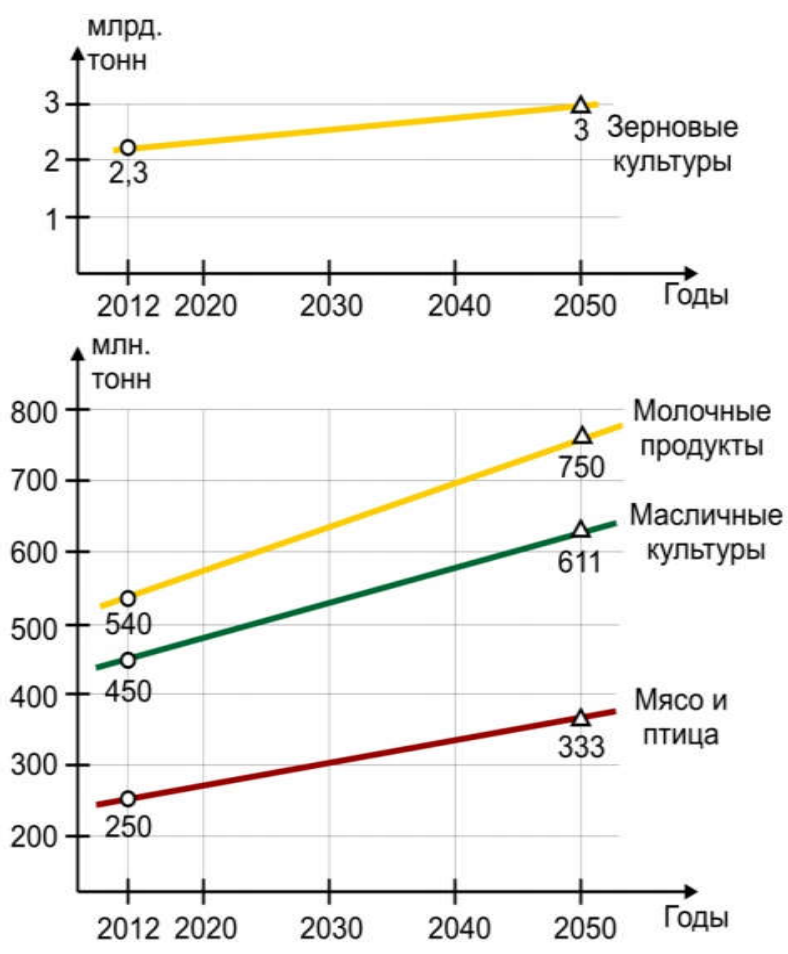

Рис.2. Прогноз роста запросов на продовольствие.

ка (возьмем отрезок в 75 лет) население Земли увеличилось в 3,5 paза. Дальнейший демографическийпрогноз (до 2050 г.) выглядит следующим образом (рис.1). Обидно за славян. Основной ресурс страны, обеспечивающий прогресс - это молодежь. Стареющая нация не выдержит конкуренции. Рассмотрим еще один график (рис.2). На первый взгляд, график как график. Все так - больше людей, больше продуктов. Хозяйка, когда на стол накрывает, всех едоков учтет. Так, да не так. Сегодня за всемирным столом еды уже всем не хватает. Как мы уже говорили, эра дешевых энергоресурсов и продуктов питания на Земном шаре закончилась. Число горожан на Земном

\begin{tabular}{|c||c|c||}
\hline Года & $\begin{array}{c}\text { Сельские } \\
\text { жители (\%) }\end{array}$ & $\begin{array}{c}\text { Городские } \\
\text { жители (\%) }\end{array}$ \\
\hline \hline 2000 & 70 & 30 \\
\hline \hline $\begin{array}{c}2020 \\
\text { (прогно3) }\end{array}$ & 45 & 55 \\
\hline \hline Потребление на душу населения мяса и рыбы \\
(кг/год)
\end{tabular}


шаре превысило число людей живущих в селе. А, как известно, рацион питания горожанина отличается от рациона питания селянина. Вот данные по Китаю, стране, которая в силу большой доли населения Земли во многом определяет динамику агробизнеса.

Именно этим можно объяснить рост потребности на душу населения таких культур как пшеница, но еще более соя и кукуруза, ибо эти культуры являются кормовой базой для животноводства (птицеводства, рыбоводства), основная доля продуктов которого потребляется городским населением. С учетом всего вышесказанного, рост населения Земли снижает долю сельхозугодий, приходящегося на каждого жителя, ясно, что впереди у человечества трудные времена. Сегодня в мире уже каждый седьмой житель Земли голодает, и каждые 15 секунд один человек умирает голодной смертью. Нам с Украины это не видно, ибо на каждого из нас приходится земли $\mathrm{c} / \mathrm{x}$ назначения в шесть раз больше, чем в среднем на жителя планеты, и какой земли! Справка. На одного украинца приходится 0,72 га, на турка 0,3 га, на индуса 0,12 га, на египтянина 0,04 га. Цена земли растет, ибо значимость ее в судьбе человечества выходит на первый план. Так, например, в некоторых землях Германии цена 1 га с/х земли стоит более 25000 $€$. Украина вошла в мировой рынок и цены на $\mathrm{c} / \mathrm{x}$ продукцию подтянулись к мировым.

Признаки начала нового состояния мира очевидны - миграция людей из густонаселенных бедных стран в относительно более успешные, так называемое «эхо колоний», когда мигранты, зная язык бывшей метрополии, гонимые низким уровнем жизни устремляются на территории некогда государствколонизаторов (из Северной Африки в Европу, из Средней Азии в Россию) кроме того, из Китая в Зауралье, Сибирь и Дальний Восток, и со всего мира в США и Канаду. Все чаще в ходу термины «экономическая война», «экономическая колония», «продовольственное оружие». Продовольственный кризис неизбежен, но смягчить его можно и эта задача под силу точной агротехнологии.

Точная агротехнология - технология будущего, но начинается она уже сегодня. Человек должен так знать поле, чтобы дать ему все для его жсизни и получить от поля максимум для жизни своей.

Не малые резервы лежат в оптимизации размещцения растений на поле.

Традиционно подсолнечник сеется при ширине между рядами 70 cм. Именно необходимость механического удаления сорняков между рядами определило принципиально неверную технологию расnределения растений на поле.

Сегодня, когда точный высев, практически, становится нормой, т.е. высевать строго заданное количество растений на единицу площади поля при равнораспределении растений технически возможно, настало время реализовать научно разработанные рекомендации распределения растений на поле с учетом оптимальной площади питания и густоты сева, уменьшающие поверхность прямого попадания солнечных лучей. Именно такое размещение позволяет:
- получить максимальный урожай;

- создать затенение поверхности поля и не оставить света сорняку;

- исключить конкуренцию растений;

- не допустить нагрева почвы солнечными лучами между растениями, тем самым исключить ик-излучения нагретой почвы и защитить растения от перегрева.

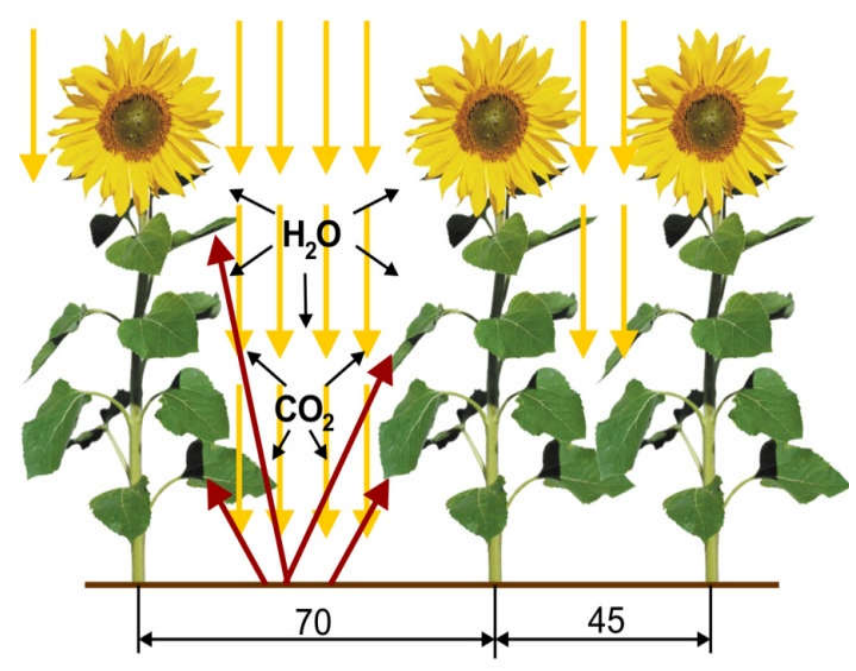

Рис. 3. Схема теплового баланса при междурядьях 70 и 45 см.

В предыдущем материале применительно к кукурузе было показано, как воздействует ик-поток на растения при попадании солнечных лучей на свободное поле между рядами. Аналогичная картина и у подсолнечника (рис.3).

Мощный поток тепловой энергии в виде икизлучений идет от нагретой солнечными лучами почвы между рядами и облучает внутреннюю поверхность листа, куда природа спрятала устьица для испарения воды от солнечной энергии. Да и трехатомные молекулу воды $\left(\mathrm{H}_{2} \mathrm{O}\right)$ и углекислого газа $\left(\mathrm{CO}_{2}\right)$ добавляют «жару». Достаточно сказать, что в жаркую солнечную погоду температура живого листа подсолнечника отличается от температуры мертвого на 5$7^{\circ} \mathrm{C}$. Как надо испарять воду, чтобы за счет ее испарения так охлаждать лист? А если учесть, что площадь листовой поверхности подсолнечника $\sim 4 \mathrm{M}^{2}$ на $1 \mathrm{~m}^{2}$ поля, то становится понятно, почему подсолнечник как насос вытягивает воду с нижних горизонтов.

Если рассматривать процесс с чисто физических позиций, то получается, что на единицу площади поля приходится фиксированный поток солнечной энергии, междурядье постоянное - 70 см, КПД фотосинтеза определенное генетикой подсолнечника также постоянно, то должно быть какое-то оптимальное количество растений на единицу площади поля (га), не зависящее от сорта, сроков сева и других параметров. Т.е. урожайность должна быть выше именно при этом оптимальном количестве растений перед уборкой. Анализ данных выполненный за период 25 лет показал наличие такой оптимальной величины >50 тысяч растений на га перед уборкой при междурядье 70 см (рис. $4,5,6,7,8)$. 


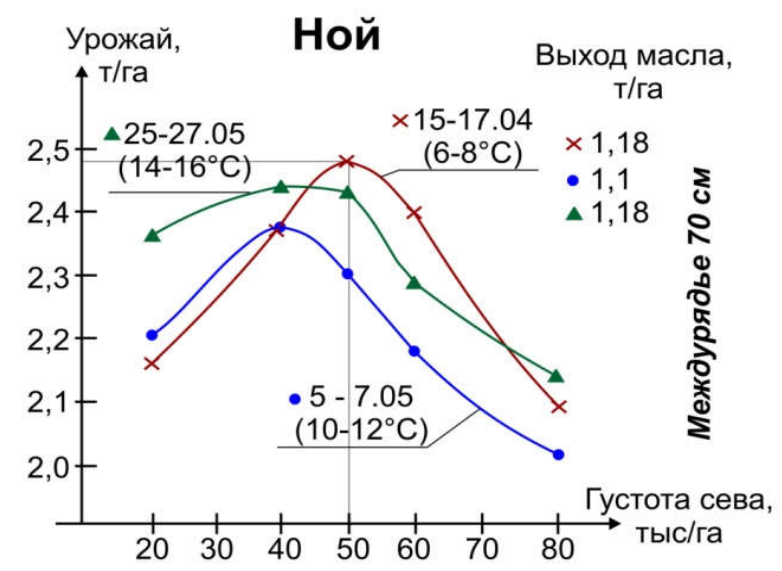

Рис.4. Зависимость урожайности и масличности гибрида Ной от сроков и густоты посева.

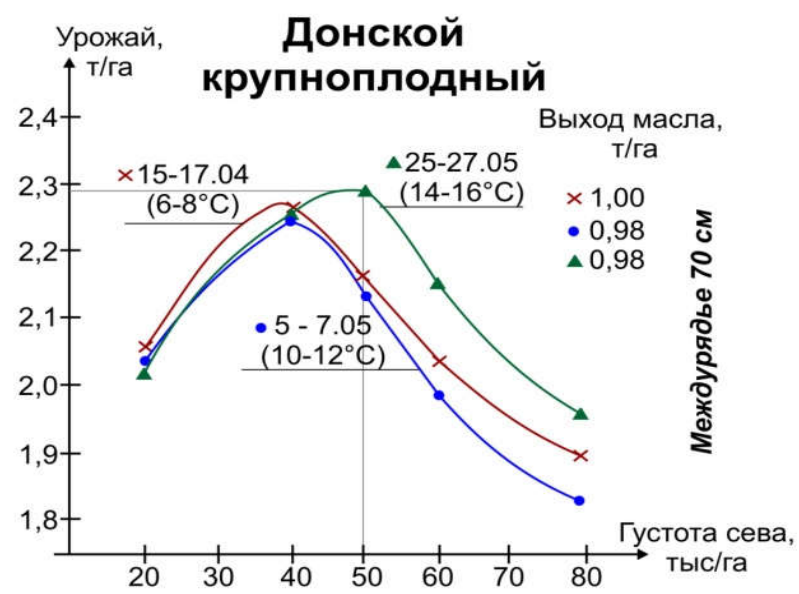

Рис.6. Зависимость урожайности и масличности гибрида Донской крупноплодный от сроков и густоты посева.

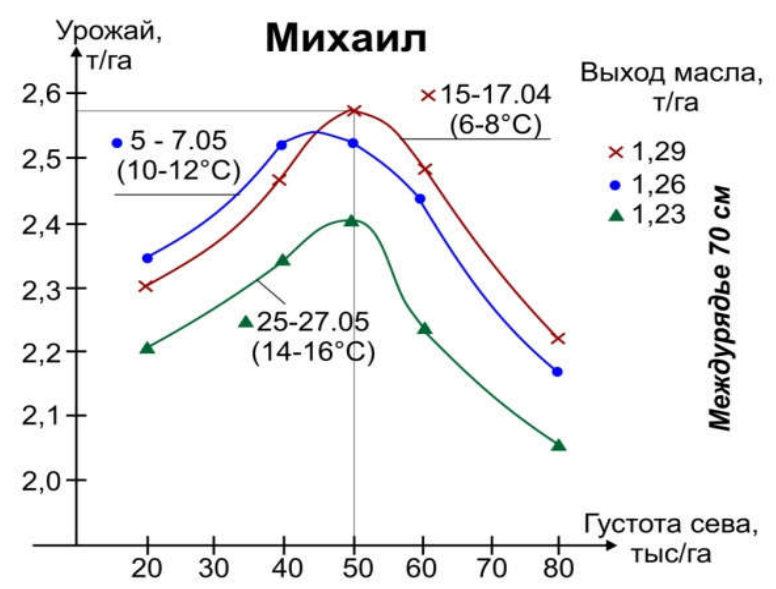

Рис.8. Зависимость урожайности и масличности гибрида Михаил от сроков и густоты посева.

Если равнораспределить эти 50 тысяч растений на поле, то чисто геометрически равнораспределенные растения при междурядье 40 см будут отстоять одно от другого на 45 cм (рис.9). Таким образом, будет равномерное распределение питания для корневых систем и количество солнечной радиации для фотосинтеза. Естественно возникает вопрос: при таком распределении растений на поле должна быть и

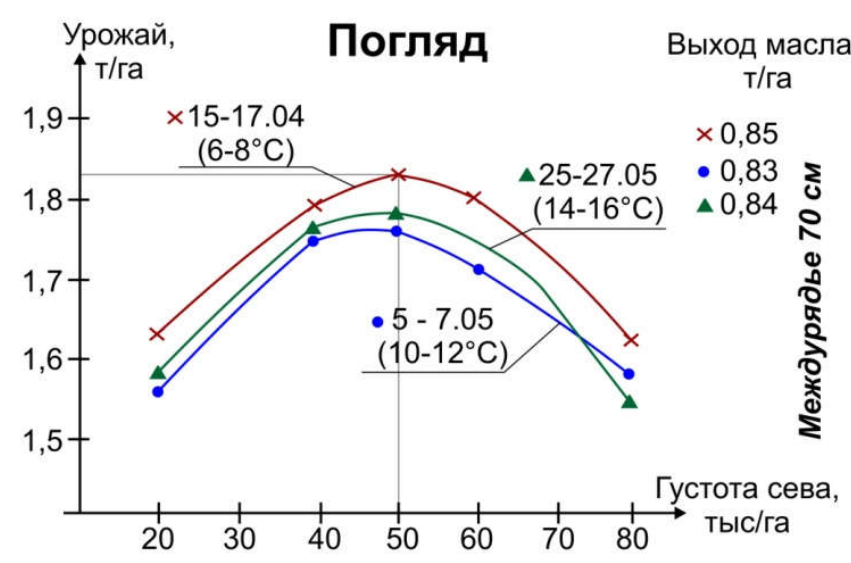

Рис.5. Зависимость урожайности и масличности гибрида Погляд от сроков и густоты посева.

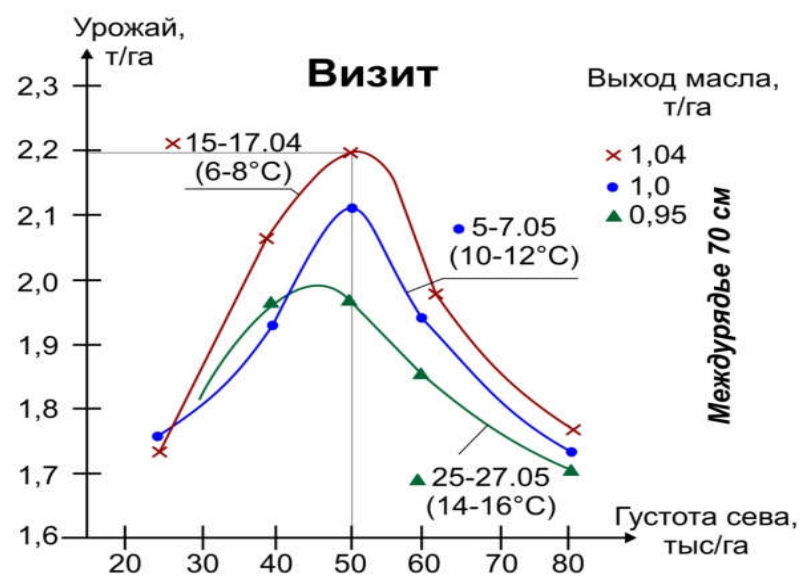

Рис.7. Зависимость урожайности и масличности гибрида Визит от сроков и густоты посева.

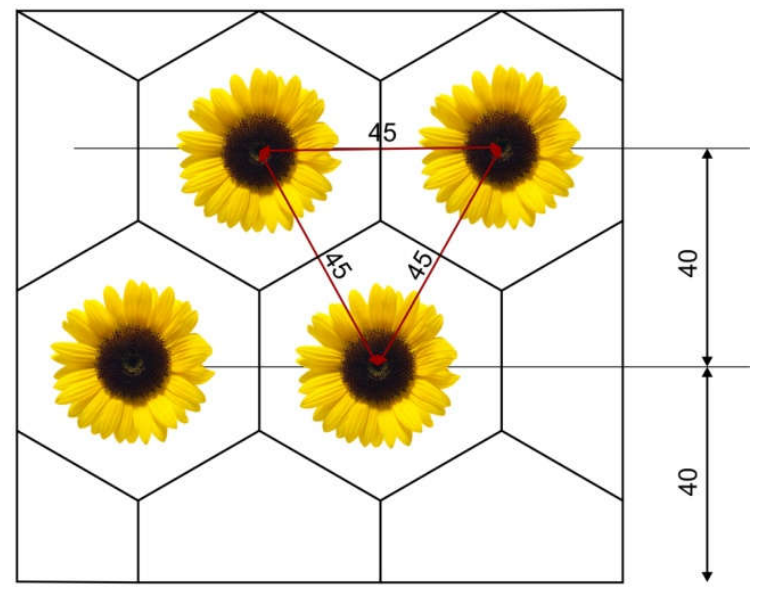

Рис.9. Фрагмент поля 1 кв.м (60 тыс.шт./2а).

другая оптимальная норма стояний растений перед уборкой.

Другого ответа быть не должно, ибо при междурядье 70 см происходит конкуренция между растениями за воду, питание и свет (рис.10, 11).

Естественно, что при существующей схеме посева неравномерность освещения растений существенно снижает эффективность фотосинтеза, а вытянутые прямоугольники почвы, приходящиеся на кор 


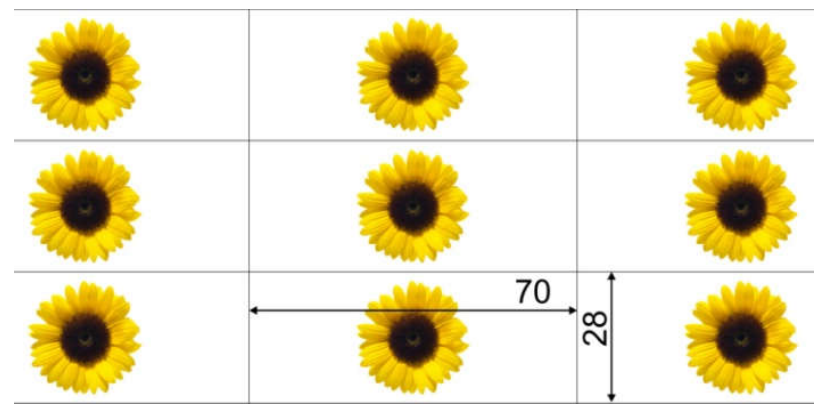

Рис.10. Фрагмент поля подсолнечника при междурядье 70 см (50 тыс.растений).

невую систему одного растения, не обеспечивают полное потребление питательных веществ. То есть растения скучены в рядах, что усиливает конкуренцию между ними за влагу, свет и питательные вещества уже в ранний период жизни, что при одинаковых факторах внешней среды сдерживает возможность повышения урожайности за счет более продуктивного использования влаги, питательных веществ и максимальной утилизации солнечной радиации. Поэтому при посеве с междурядьями 70 cм только за счет повышения числа растений в рядке не удавалось повысить урожайность подсолнечника многим исследователям (Андрюхов В.Г., Шипилов М.А., 1984; Деревянко В.А., Лиман П.В., 1990; Харченко Н.И., 1993) [1].

Необходимо максимально помогать растению в его жизнедеятельности, что и является целью агротехнологии. Конкуренция растений за влагу (влага несет питательные вещества) начинается ужсе с фазы бутонизации и далее только усиливается вплоть до созревания. Оптимальное размещение растений в поле позволяет в большей мере развить корневую систему, а значит и продуктивность растения.

К ограничению урожайности приводит и неравномерное размещение растений в рядах (Дьяков

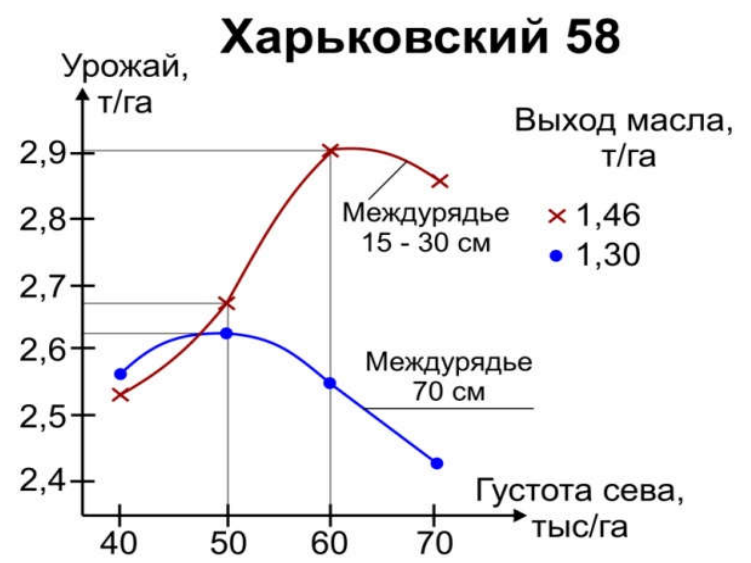

Рис.12. Урожайность гибрида Харьковский 58 в зависимости от величины междурядья и густоты сева.

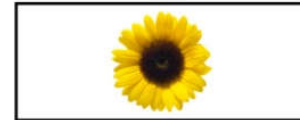

50 тыс./га $70 \times 28$

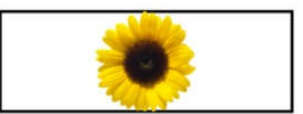

60 тыс./га $70 \times 24$

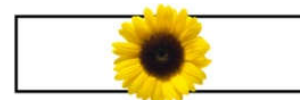

80 тыс./га $70 \times 18$

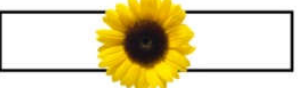

100 тыс./га $70 \times 14$

Рис.11. Сужение зоны питания растения подсолнечника при увеличении густоты в ряду.

А.В., 1983). При равномерном размещении улучшается освещение каждого растения и повышается продуктивность фитоценоза. Поэтому в опытах И.И. Рясниченко (1980), З.Б. Борисоника, Ю.Р. Каменева (1988), В.Н. Сонливого, А.И. Остапенко (1986), В.А. Дробот (1990) и многих других исследователей уменьшение ширины междурядий $\boldsymbol{c} 70$ до 40 cm nрu пунктирном способе посева способствовало повыиению урожайности подсолнечника на 0,57 т/га [1]. Подсолнечник лучше других культур угнетает в посеве сорняки. Они развиваются медленно и часто не дают семян, которые могут засорить следующую культуру. Чем гуще и равномернее стеблестой, тем сильнее проявляется эта его способность. Итак, резюме - не заставляйте растения тратить энергию на борьбу друг с другом.

Если это так, то при равнораспределении растений на поле оптимальное их количество должно сместиться от 50 тысяч растений на гектар в сторону большего количества.

Именно это подтверждает обработка данных по урожайности различных гибридов и сортов подсолнечника - оптимальная норма стояния при равнораспределении растений смещается в сторону большего количества и составляет величину 60 тыс.шт. растений на га перед уборкой (рис.12-15).

\section{Одесский 123}

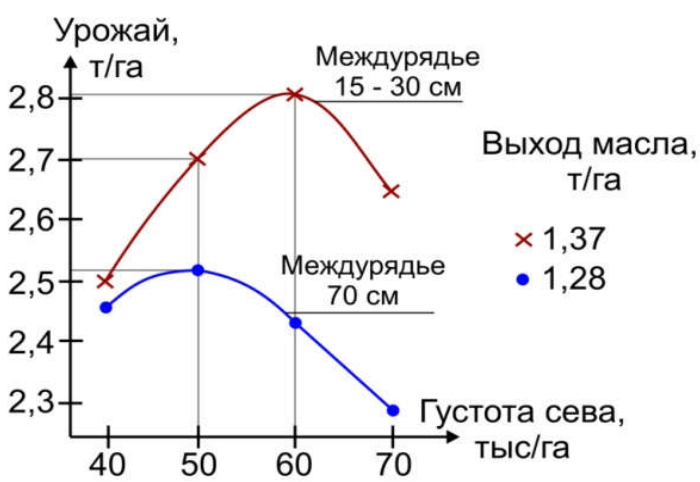

Рис.13. Урожайность гибрида Одесский 123 в зависимости от величины междурядья и густоты сева. 


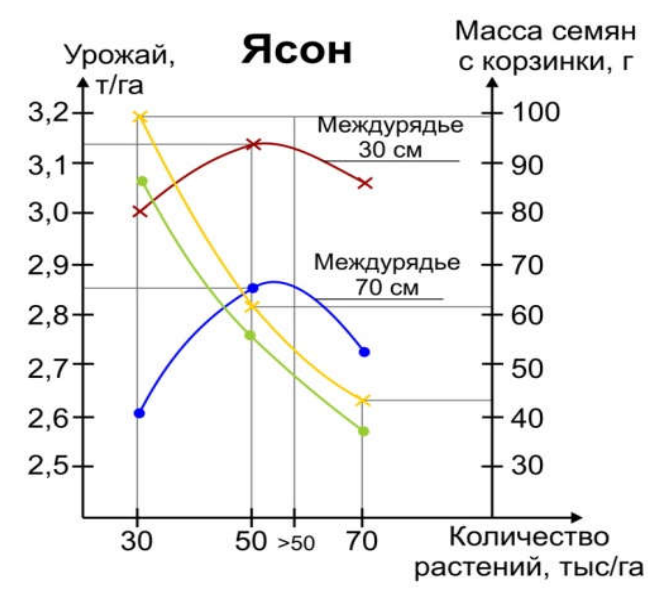

Рис. 14. Урожайность подсолнечника Ясон в зависимости от густоты сева и междурядья.

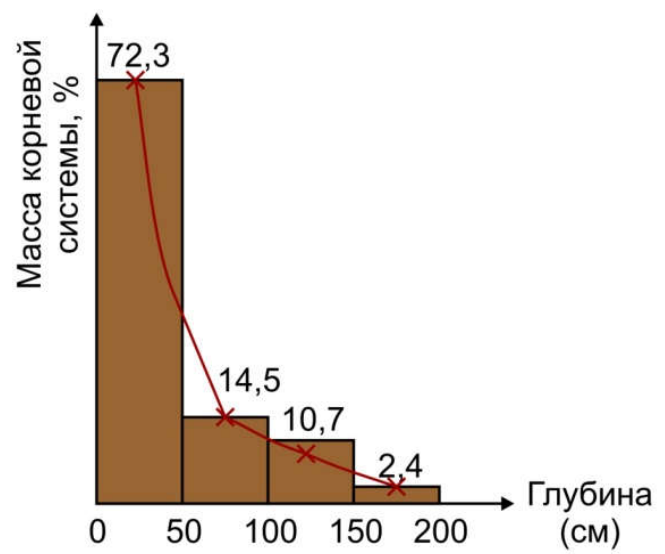

Рис.16. Весовое распределение массы корневой системы одного растения (среднее).

Более высокие урожаи подсолнечника при междурядьях 40 c.⿲丿丨 чем при 70 cм, объясняют разными причинами и прежде всего оптимальной формой площади питания, приближающиеся к квадрату (или кругу). Это ослабляет конкуренцию между культурными растениями за основные факторы жизни, создает им лучшие условия для болем равномерного использования воды, питательных веществ и света. Растения оптимально затеняют почву, улучшая ее температурный режим и снижая непродуктивное испарение влаги, полнее препятствуют разрушительному действию дождевых капель на структуру почвы и др. [2].

Как было сказано выше, чем меньшая поверхность поля доступна для прямых солнечных лучей, тем легче растению перенести засуху. Для подсолнечника это особенно значимо, ибо поток икизлучений от перегретой почвы попадает на нижнюю часть листьев, количество которых у одного растения около 30 и суммарная площадь их достигает $1 \mathrm{~m}^{2}$ на одно растение.

Оптимизация размещения подсолнечника на поле особенно значима в засушливые годы, когда растение нагревается высокой температурой воздуха, прямыми солнечными лучами и мощным потоком икизлучений от незатененной поверхности почвы (особенно при пахотной технологии землеобработки). В

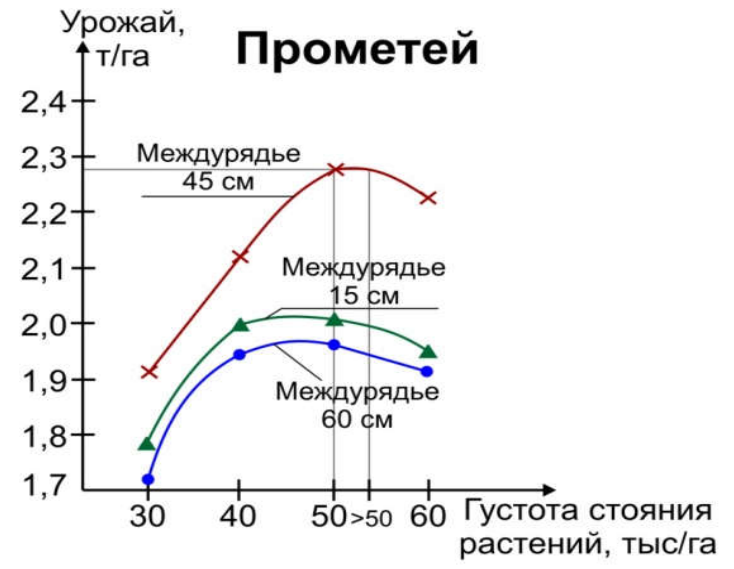

Рис.15. Влияние густоты стояния сорта Прометей и ширины междурядья на урожайность (средние данные за три года Иваценко В.А.).

такой ситуации растение в борьбе за выживаемость должно испарять воду особенно интенсивно.

Таким образом, исходя из чисто линейных и площадных оптимизаций, можно утверждать, что при севе подсолнечника, с целью получения максимального урожая и выхода масла с га, необходимо обеспечивать ширину междурядья 40 см при густоте стояния 60 mыс./za.

Такое размещение позволяет обеспечить равноудаленность растений равное $45 \mathrm{~cm}$, что защитит почву от перегрева прямыми солнечными лучами, а значит устранит ик-излучения на растения от нагретой почвы и тем самым уменьшит потери влаги на испарение, усилит угнетение сорняков, затененных равномерно расположенными листьями, которые при этом более полно поглощают солнечную радиацию, корневая система растений пронизывает весь объем почвы между растения$\boldsymbol{м u}$, тем более, что 2/3 массы корневой системы подсолнечника распределены в верхнем слое почвы (рис.16), что наряду с улучшением воздушного питания, позволяет эффективно использовать всю среду обитания для формирования повышенной продуктивности подсолнечника [1] .

Несколько слов о значимости поступающей энергии от солнца на образование и накопление биологически питательных веществ. Чем больше листовая поверхность работает как «фабрика утилизации солнечной энергии», тем мощнее растение. У подсолнечника листовая поверхность составляет около $1 \mathrm{~m}^{2}$, т.е. $5 \mathrm{~m}^{2}$ на $1 \mathrm{~m}^{2}$ поля и надо, чтобы вся эта поверхность была максимально освещена солнцем. Это особенно важно для подсолнечника в фазе образования корзинки.

В связи с более полным охватом корнями подсолнечника почвы между растениями почвенная влага используется эффективнее и в большем количестве, чем при более широких междурядьях, где только отдельные корни достигают их середины. Так, в опытах в слое почвы 0-150 см продуктивной влаги осталось при междурядьях 40 cм - 48,5 мм, 70 см - 66,4 мм. Увеличение густоты стояния растений и уменьшение ширины междурядий способствовало ускорению созревания подсолнечника на 3-4 суток [1]. 


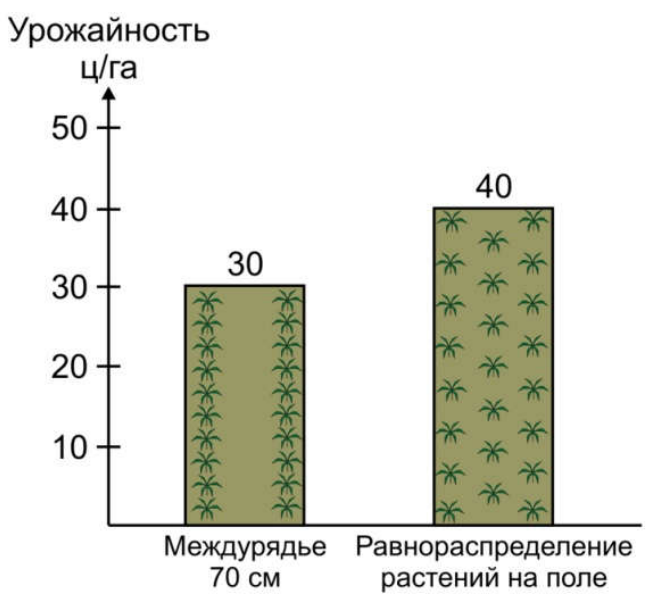

Рис.17. Урожайность подсолнечника в Бориспольском филиале компании «Агро-Регион» при междурядье 70 см и равнораспределении растений на поле (66 mыс.ит./гa, 2014 г.) [3].

Таблица 1

\begin{tabular}{|c|c|c|c|}
\hline \multirow{3}{*}{ Организация } & \multicolumn{2}{|c|}{ Междурядье } & \multirow{3}{*}{$\begin{array}{c}\text { Прибав- } \\
\text { ка, } \\
\text { т/га }\end{array}$} \\
\hline & $30-35 \mathrm{~cm}$ & $70 \mathrm{~cm}$ & \\
\hline & \multicolumn{2}{|c|}{$\begin{array}{c}\text { Урожайность, } \\
\text { т/га }\end{array}$} & \\
\hline $\begin{array}{l}\text { ОАЗТ «Агро- } \\
\text { Союз» Синельни- } \\
\text { ковский р-н }\end{array}$ & 2,85 & 2,6 & 0,25 \\
\hline $\begin{array}{l}\text { ТОВ «Лада» Кри- } \\
\text { ничанский р-н }\end{array}$ & 2,3 & 1,85 & 0,45 \\
\hline $\begin{array}{l}\text { ООО «Свитанок» } \\
\text { Новомосковский } \\
\text { p-н Днепр. области }\end{array}$ & 2,8 & 2,5 & 0,3 \\
\hline Среднее & 2,65 & 2,32 & "0,33 \\
\hline
\end{tabular}

При разных сроках сева у растений формировались полноценные корзинки, но разной продуктивности, что свидетельствует о сильном влиянии конкурентных стрессов. Так, масса семян с корзинки в годы исследований равнялась: при междурядьях 40 $\boldsymbol{c м}$ и густотах стояния растений 40,60 и 70 mbc./za 96,$8 ; 61,7 ; 43,4$ г, 70 cм $-85,7 ; 55,9 ; 38,8$ г, что и определило максимальную урожайность при густоте стояний 60 mbc./2a и междурядье 40 cм.

После того, как было предложено такое распределение подсолнечника на поле, естественно оценить экономическую эффективность такой оптимизации.

На сегодня в производстве уже имеются положительные результаты, подтверждающие правомер-

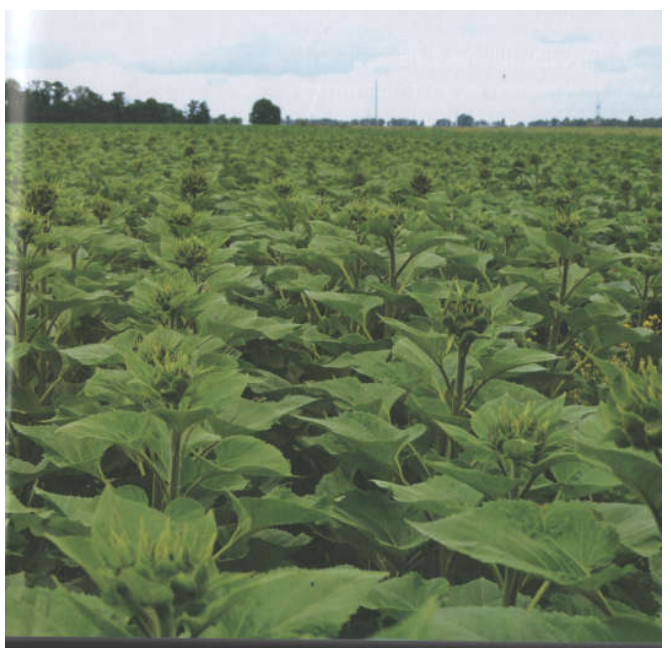

Рис.18. Подсолнечник при междурядье 35 см.

ность рекомендации по технологии сева. Так, в ОАЗТ «Агро-Союз» Синельниковского района в среднем за 2 года при севе с междурядьями 30-35 cм получили урожайность подсолнечника на площади 40 га по $2,85 \mathrm{~m} / 2 \mathrm{a}$, а на широкорядном посеве $(70 \mathrm{~cm})-2,6$ $\boldsymbol{m} / \mathbf{a} \boldsymbol{a}$, в ТОВ «Лада» Криничанского района в 2009 г. на 30 га соответственно - 2,3 и $\mathbf{1 , 8 5} \mathbf{m} / \mathbf{2}$. В ООО «Свитанок» Новомосковского района Днепропетровской области в 2008 - 2009 гг. на площади 70 га собрали урожай гибрида Ясон соответственно 2,8 u 2,5 $\boldsymbol{m} / \mathbf{a} \boldsymbol{a}$ (табл. 1).

Если учесть удешевление агротехнологии за счет естественного подавления сорняков (отсутствие междурядной обработки) на, практически, полностью затененном растениями подсолнечника поле, то при сегодняшних ценах на подсолнечник прибыль приближается к 2 млн. грн. на поле площадью 1000 га.

Еще более сильное доказательство эффективности равнораспределения растений подсолнечника на поле получено в 2014 году в филиале компании «Агро-Регион» (рис. 17) [3], где разница в урожайности подсолнечника при равнораспределенном варианте размещения растений по сравнению с контролем (междурядье 70 см) составила 1 т/га. Прибыль легко подсчитать и добавить к ней еще экономию на страховых гербицидах, которые не понадобились, поскольку затенение растениями поверхности поля естественно сдержало рост сорняков (рис.18).

Таким образом, на примере равнораспределения подсолнечника на поле, как и на примере кукурузы, убедительно доказывается преимущества такого похода.

\section{ЛИТЕРАТУР}

1. Ткалич И.Д. Цветок солниа (основы биологии и агротехники подсолнечника) : монография/ И.Д. Ткалич, Ю.И. Ткалич, С.Г. Рычик// под ред. док-ра с.-х. наук, проф. И.Д. Ткалича. - Днепропетровск, 2011. - 172 c.

2. Васильев Д.С. Подсолнечник. - М.: Агропромиздат, 1990. - 174 с.: ил.

3. Паменко О.И., директор бориспольской филии компании «Агро-Регион». Подсолнечник с междурядьем 35 см./Паменко О.И.// Агроном. - 2015. - №3 (49). - август. - С.8.

Надійшла 13.10.2015. До друку 25.10.2015 Адреса для переписки: $\mathrm{OOO}$ «Спецэлеватормельмаш

Украина, г.Харьков, ул.Исполкомовская, 32 Тел./факс: (057) 3738060, (050) 1575740

Email: specmash@imperija.com, http://agro.imperija.com

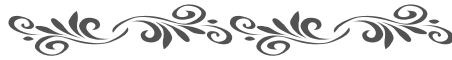

